\title{
Sistem Perancangan Web Penjualan Material Bangunan Pada PT Bangun Tiara Teknik
}

\author{
Bani Siregar ${ }^{1}$, Firstianty Wahyuhening Fibriany ${ }^{2}$ \\ ${ }^{1}$ Sistem Informasi, Universitas Bina Sarana Informatika \\ e-mail: bani.srg@gmail.com \\ ${ }^{2}$ Sistem Informasi, Universitas Bina Sarana Informatika \\ e-mail: firstianty.fbr@bsi.ac.id
}

Cara Sitasi: Siregar, B., \& Fibriany, F. W. (2019). Sistem Perancangan Web Penjualan Material Bangunan Pada PT Bangun Tiara Teknik. Jurnal Teknik Komputer, 113-118. doi:10.31294/jtk.v4i2

\begin{abstract}
Web-based information systems technology is one of the media information that is efficient and effective in the dissemination of information that can be accessed by anyone, anytime, and anywhere. Currently, many companies are already making use of web-based information systems technology to help his efforts in promoting his company, to introduce its product, getting consumers more, making transactions faster and provide satisfying service for consumers. PT. Bangun Tiara Teknik is a company engaged in the field of building materials. Sales system that exists today of PT. Bangun Tiara Teknik is still done manually, where starting from the process of supply of goods, the ordering of merchandise, the deals, the creation of shipping documents, to reporting, so it takes a lot of time and in create a document and are still often goes wrong in terms of record keeping and input data by the sales section. The results of the design of this web-based information system is the best solution to solve the problem. Error logging orders can be minimized and reporting can be done appropriately. Therefore, the authors are interested in making the design of information system of sales with web-based at PT Bangun Tiara Teknik. With web-based computerized system allows the addition of a number of consumers to purchase the desired product, consumer satisfaction against the speed and accuracy of orders as well as reporting.
\end{abstract}

Keywords: Web Design, information systems, Sales of building materials

\section{PENDAHULUAN}

Pesatnya persaingan usaha saat ini, tidak terkecuali perusahaan yang bergerak dalam bidang penjualan material bangunan membuat saling bersaing untuk merebut pasar dan menambah jumlah pasar. Penjual membutuhkan suatu sistem yang baik untuk menjalan kan usaha tersebut. Dengan adanya sistem yang baik perusahaan tersebut akan mendapatkan keuntungan yang maksimal.

Teknologi Informasi berbasis web merupakan salah satu media informasi yang efektif dan efisien dalam penyebaran informasi yang dapat di akses oleh siapa saja, kapan saja, dan dimana saja. Hanya dari rumah calon pembeli dapat melihat produk-produk yang ditawarkan pada layar komputer, mengakses informasinya, memesan dan membayar dengan pilihan yang tersedia. Calon pembeli dapat menghemat waktu dan biaya karena tidak perlu datang ke toko atau tempat transaksi. Transaksi secara online dapat menghubungkan antar penjual dan calon pembeli tanpa dibatasi oleh suatu ruang dan waktu.

Menurut Taufik (2017) "Sistem Informasi merupakan sistem yang ada dalam organisasi yang dipertemukan dengan kebutuhan pengolahan transaksi harian untuk mendukung fungsi operasi organisasi yang bersifat manajerial dengan kegiatan strategi dari organisasi untuk dapat menyediakan laporan-laporan yang memerlukan untuk pihak di luar organisasi".

Sistem informasi penjualan yang selama ini diterapkan oleh PT. Bangun Tiara Teknik adalah dengan cara manual. Mulai proses penawaran barang, pemesanan barang, transaksi, pembuatan dokumen sampai pembuatan laporan. Sehingga membutuhkan waktu yang sangat banyak dan dalam pembuatan dokumen transaksi penjualan masih sering terjadi kesalahan, terutama dalam hal penginputan data. Dalam menawarkan produknya masih menggunakan sistem manual, dimana pembeli harus datang ke toko PT. Bangun Tiara Teknik untuk membeli produk yang diinginkan atau pembeli menelepon, mengirim email untuk meminta informasi produk yang dijual oleh PT. Bangun Tiara Teknik. Sehingga pembeli membutuhkan waktu yang cukup banyak.

Atas dasar identifikasi masalah yang telah dipaparkan, maka rumusan masalah yang diangkan adalah bagaimana membuat suatu sistem 
perancangan penjualan material bagunan yang baik dan terpercaya yang dapat meningkatkan pendapatan perusahaan.

\section{METODOLOGI PENELITIAN}

Dalam penulisan penelitian ini penulis melakukan pengumpulkan data dengan menggunakan beberapa metode pengembangan perangkat lunak. Metode pengumpulan data yang digunakan adalah sebagai berikut:

\section{Metode Pengembangan Perangkat Lunak}

Metode yang digunakan pada pengembangan perangkat lunak penelitian ini adalah dengan menggunakan metode Air Terjun atau waterfall methode. Menurut Sulianta (2017), System Development Life Cycle (SDLC) atau metode air terjun ini terdapat beberapa fase. Fase tersebut menjelaskan langkah-langkah kerja yang harus dilakukan hingga sistem akhirnya digunakan.

\section{a. Fase Perencanaan}

Fase Perancanaan adalah fase paling awal yang dalam mengembangkan sistem informasi atau perangkat lunak. pada fase ini akan dicari tahu apakah alasan membangun sistem informasi masuk akal dan dapat menjadi solusi dari problem yang di hadapi perusahan.

\section{b. Fase Analisis}

Fase analisis merupakan tahap dimana fokus bertumpu pada pencarian informasi yang dianggap penting dalam menentukan kebutuhan sistem informasi kelak. Kiat-kiat mendapatkan informasi yang dilakukan antara lain: Melakukan peninjauan lapangan (observasi), pemberkasan, jajak pendapat (survey), wawancara (interview).

\section{c. Fase Desain}

Fase desain ditujukan untuk memodelkan terlebih dahulu sistem yang nantinya akan di buat.

d. Fase implementasi merupakan fase yang ditujukan dalam mendapatkan semua sumber daya sistem informasi dan mulai membangun sistem informasi.

\section{e. Fase Penggunaan}

Fase penggunaan adalah fase terlama dalam Sistem Development Life Cycle, karena sistem informasi masih bisa digunkan dalam memenuhi kebutuhan transaksi perusahaan, maka itu pula waktu keberlangsungan fase penggunaan.

\section{Metode Pengumpulan Data}

Teknik pengumpulan data yang digunakan oleh penulis dalam pembuatan penelitian ini adalah sebagai berikut :

\section{a. Observasi (Observation)}

Observasi merupakan pengumpulan data dengan pengamatan langsung terhadap objek yang akan diteliti, yaitu mengenai proses penjualan yang dilakukan PT. Bangun Tiara Teknik kemudian dilakukan pencatatan terhadap hasil observasi.

b. Wawancara

Setelah melakukan observasi, penulis melakukan tanya jawab untuk memperoleh informasi tentang produk, cara pemesanan, pencatatan yang dilakukan perusahan tersebut selama ini.

\section{c. Studi Pustaka (Literature Study)}

Penulisan penelitian ini ditunjang juga dengan berbagai literatur. Literatur diambil dari berbagai sumber buku atau $e$-book dan juga dari berbagai jurnal yang berkaitan dengan sistem penjualan online (e-commerce).

\section{HASIL DAN PEMBAHASAN}

PT. Bangun Tiara Teknik merupakan perusahaan yang bergerak dibidang keperluan proyek konstruksi. Perusahaan ini berdiri sejak tahun 2012 oleh Nikson Siregar. Visi dan misi perusahaan ini adalah untuk meningkatkan kepercayaan konsumen untuk kerja sama yang baik dan transparan. Perusahaan ini beralamat di Jl. H.Ten 1 No.1, Rawamangun, Jakarta Timur.

Perusahaan ini memiliki berbagai macam produk konstruksi. Produk yang dijual merupakan produk biasa digunakan oleh para kontraktor umum (general contructor), pabrikasi dalam sebuah proyek partai kecil, partai menengah maupun partai besar. Adapun jenis produk - produk yang ditawarkan oleh PT. Bangun Tiara Teknik digolongkan menjadi sebagai berikut:

a. Pipa: Carbon Steel (API 5L-B, ASTM 106 B, ASTM A-333)

Stainless Steel 304,304L,316,316L,SCH10,20,40,80 Seamless \& Welded.

b. Fitting: Carbon Steel ASTM 234, SCH 40,80, Stainless Steel

ASTM A- 403,304,304L,316,316L,SCH. 10,20, Screw/Butt Weld.

c. Flange: Carbon Steel ASTM A105 \& Stainless Steel ASTM A182. JIS-ANSI,5K,10K,20K Class 150,300,600 Wel Neck, Slipon \& Blind Flange.

d. Valve: Gate, Globe,Check, Strainer, Ball, Butterfly, Knife, Diaphragm Valve (Class 150,300, Jis, $10 \mathrm{~K}, 20 \mathrm{~K})$. Bronze

e. Control Valve: Pressure Reducing Valve, Safety 
Valve.

f. Instrument : Fitting-Fitting, Valve, Tubing SUS 316. Cable.

\section{Permasalahan Pokok}

Setelah dilakukan penelitian dan pengamatan pada PT. Bangun Tiara Teknik, berikut ini beberapa permasalahan yang ditemukan, yaitu:

a. Dalam menawarkan produknya PT Bangun Tiara Teknik masih menggunakan sistem manual, dimana pembeli harus datang langsung ke toko PT. Bangun Tiara Teknik untuk membeli produk yang diinginkan. Selain datang ke toko langsung, pembeli dapat melakukan pembelian melalui telepon maupun mengirim email untuk meminta informasi produk yang di jual oleh PT. Bangun Tiara Teknik. Sehingga, pembeli membutuhkan waktu yang cukup banyak.

b. Dalam membuat dan mencatat dokumen transaksi masih sering terjadi kesalahan dalam hal pengetikan, Hal ini disebabkan karena sistem yang dilakukan masih manual masih menggunakan kemampuan mengingat penerima pesanan, pesanan yang kurang jelas saat diterima, dan kesalahan pengetikan, sehingga penawaran dan pelaporan pesanan pun tidak tepat.

\section{Pemecahaan Masalah}

Berdasarkan permasalah yang terjadi, berikut ini solusi alternatif yang dibuat bagaimana mengatasi masalah yang ada pada PT. Bangun Tiara Tenik :

a. Membuat perancangan sistem informasi penjualan material atau produk berbasis web, sehingga pembeli tidak perlu lagi mendatangi toko PT. Bangun Tiara Teknik untuk membeli produk yang diinginkan. Pembeli cukup mengunjungi website PT. Bangun Tiara Teknik untuk memesan produk yang diinginkan dan dapat melakukan transaksi langsung terhadap barang yang dibutuhkan. Sehingga, waktu yang dibutuhkan oleh pembeli untuk melakukan transaksi lebih cepat.

b. Membuat perancangan sistem informasi penjualan material yang berbasis web yang langsung berkaitan dengan transaksi yang berhubungan dengan kegiatan administrasi. Pembuatan ini dimaksudkan untuk mengurangi kesalahan dalam membuat dokumen-dokumen penawaran produk dan laporan transaksi penjualan yang disebabkan oleh kesalahan pencatatan.

\section{Diagram Use Case Perancangan Sistem Usulan}

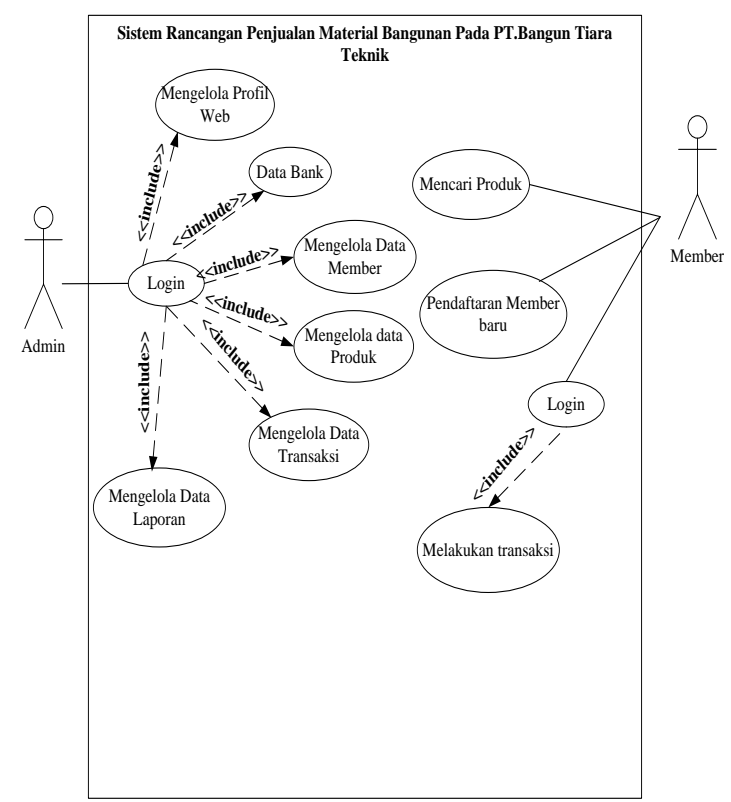

Sumber: Siregar \& Fibriany (2019)

Gambar 1. Diagram Use case

Gambar di atas menjelaskan urutan interaksi yang saling berkaitan antara sistem dan aktor. Use Case bekerja dengan cara mendeskripsikan tipe interaksi antara user sebuah sistem dengan sistemnya sendiri melalui sebuah cerita bagaimana sebuah sistem dipakai. Use Case juga digunakan untuk menbentuk perilaku (behaviour) sistem yang akan dibuat. Sebuah Use Case menggambarkan sebuah interaksi antara pengguna (aktor) dengan sistem yang ada.

\section{Rancangan Diagram Aktivitas Admin}

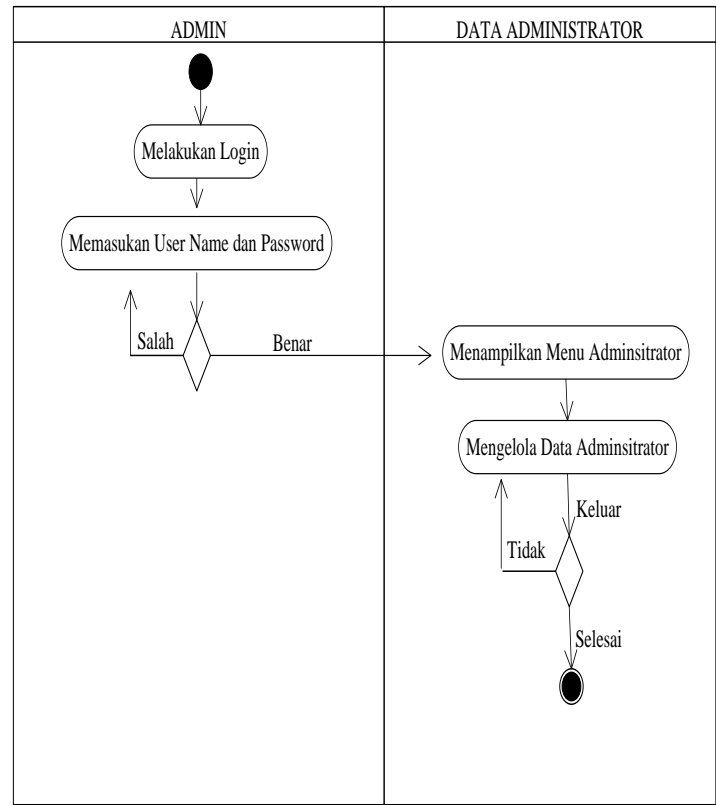

Sumber: Siregar \& Fibriany (2019)

Gambar 2. Rancangan Diagram Aktivitas Admin Aktivitas diagram yang dibuat pada Gambar 2 di atas merupakan alur kerja (workflow) atau kegiatan dari 
sebuah sistem atau menu yang ada pada perangkat lunak yang akan dibuat. Aktivitas diagram untuk admin tersebut digunakan untuk mendefinisikan urutan atau pengelompokan tampilan dari sistem / user interface dimana setiap aktivitas memiliki sebuah rancangan antar muka tampilan serta rancang menu yang akan ditampilkan pada perangakat lunak.

5. Rancangan Diagram Aktivitas Member atau Pelanggan

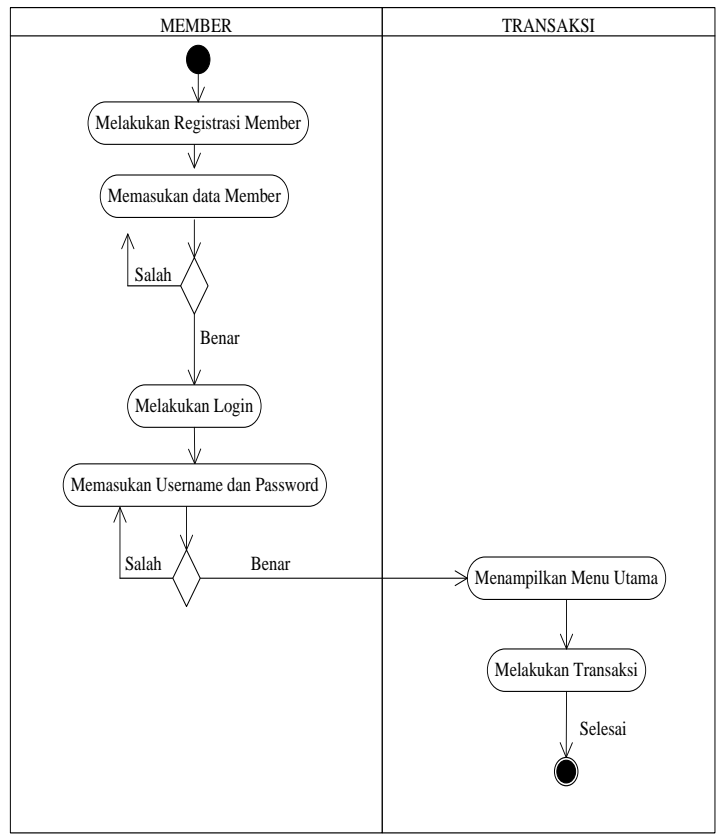

Sumber: Siregar \& Fibriany (2019)

Gambar 3. Rancangan Diagram Aktivitas Member atau Pelanggan

Aktivitas diagram yang dibuat pada Gambar 3 di atas menggambarkan alur kerja (workflow) atau kegiatan yang dilakukan dari sebuah sistem atau menu yang ada pada perangkat lunak. Aktivitas diagram untuk member atau pelanggan yang dibuat tersebut digunakan untuk mendefinisikan urutan atau pengelompokan tampilan dari sistem / user interface dimana setiap aktivitas memiliki sebuah rancangan antar muka tampilan serta rancang menu yang akan ditampilkan pada perangakat lunak yang akan dibuat.
6. Rancangan Prototype Interface Administrator

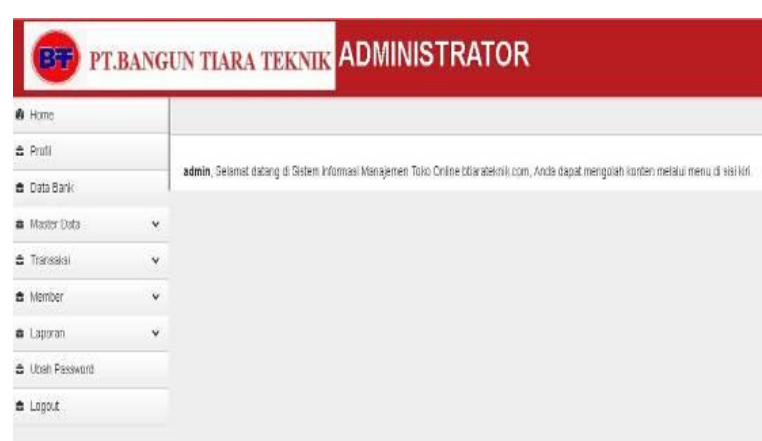

Sumber: Siregar \& Fibriany (2019)

Gambar 4. Rancangan Interface Administrator

Gamabr 4 di atas merupakan bentuk tampilan muka rancangan administator yang akan digunakan.

7. Rancangan Interface Menu Utama PT. Bangun Tiara Teknik

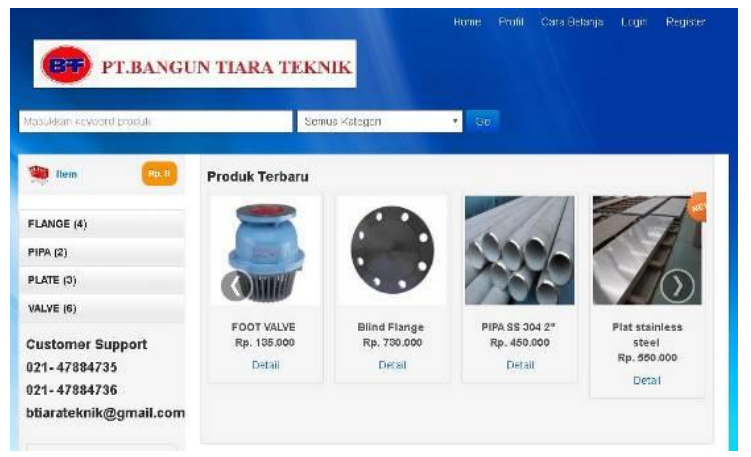

Sumber: Siregar \& Fibriany (2019)

Gambar 5. Rancangan Prototype Interface Menu Utama Pelanggan

Gambar 5 di atas merupakan bentk tampilan dari sisi pelanggan untuk melakukan kegiatan transaksi pembelian barang. 
8. Perancangan Perangkat Lunak Entity Relationship Diagram (ERD)

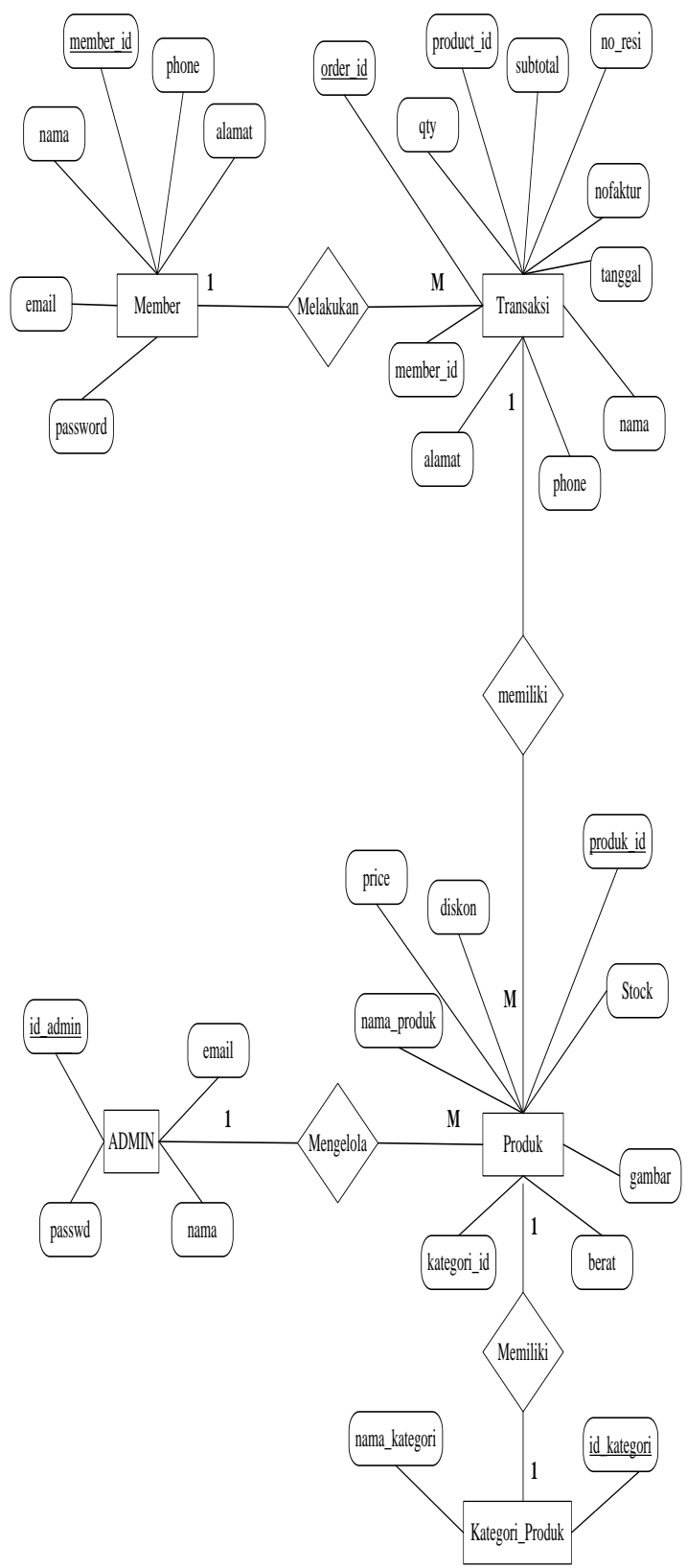

Sumber: Siregar \& Fibriany (2019)

\section{Gambar 6. Entity Relationship Diagram}

Gambar 6 di atas adalah untuk menjelaskan hubungan antar data dalam basis data berdasarkan objek-objek dasar data yang mempunyai hubungan antar relasi.

\section{Logical Record Structur (LRS)}

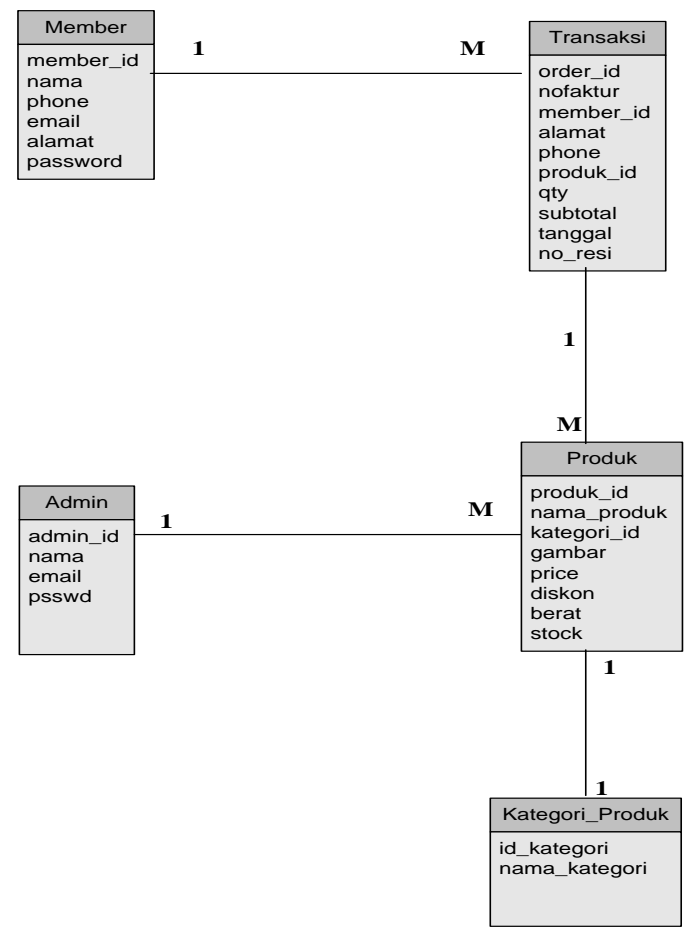

Sumber : Siregar \& Firstianty (2019)

Gambar 7. Logical Record Structur (LRS)

Gambar 7 di atas merupakan representasi dari struktur record-record yang terbentuk dari hasil antara himpunan entitas.

10. Sequence Diagram Mengelola Web

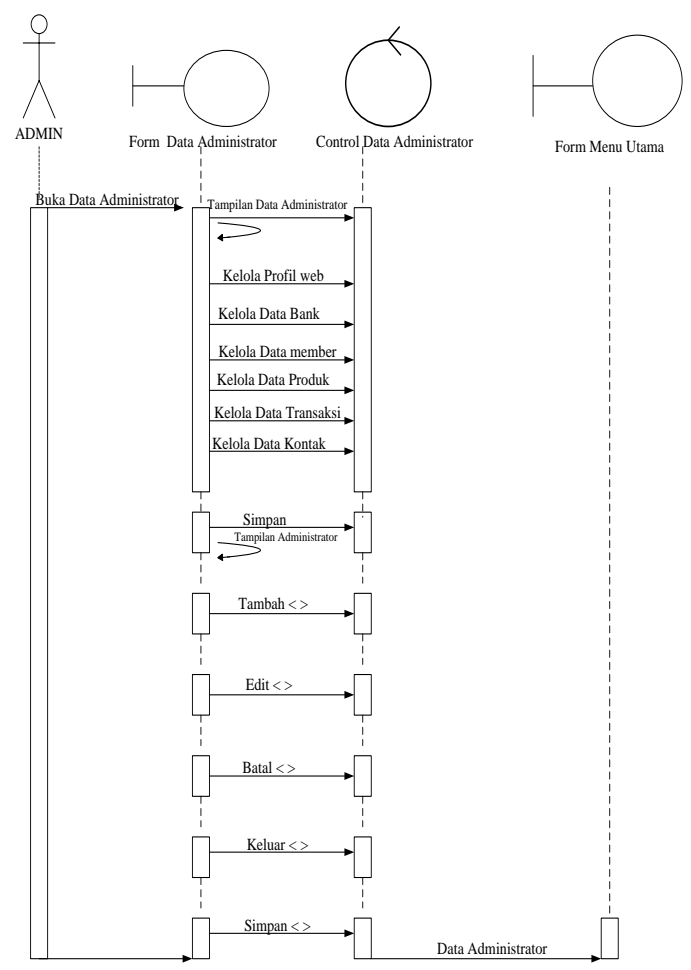

Sumber : Siregar \& Firstianty (2019)

Gambar 8. Sequence Diagram Mengelola Web 
11. Sequence Diagram Melakukan Transaksi

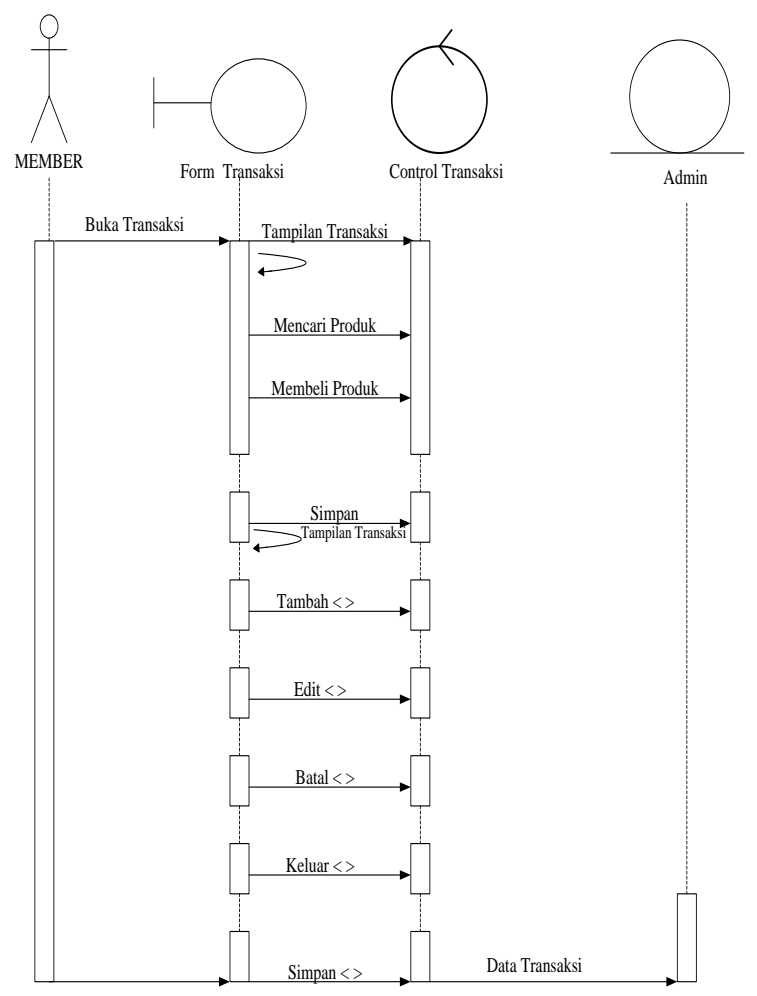

Sumber : Siregar \& Fibriany (2019)

Gambar 9. Sequence Diagram Melakukan Transaksi

Sequence Diagram pada gambar 9 di atas menggambarkan kelakuan objek pada use case dengan mendeskripsikan waktu hidup objek dan pesan yang dikirimkan dan diterima antar objek. Sequence Diagram digunakan untuk menggambar rangkaian langkah-langkah transaksi yang dilakukan sebagai respon dari sebuah event untuk menghasilkan output laporan. Diawali dari pelanggan melakukan pemesanan barang, proses transaksi, dan perubahan yang terjadi secara internal dan output apa yang dihasilkan.

\section{KESIMPULAN}

Kesimpulan dari penelitian yang berjudul Perancangan Sistem Informasi Penjualan Material Bangunan Pada PT. Bangun Tiara Teknik bahwa perancagan Sistem Informasi yang dihasilkan ini dapat memudahkan perusahaan untuk menawarkan produk dengan baik dan meningkatkan omset perusahaan. Selain itu, pembeli dimudahkan dalam membeli produk, pembeli tidak perlu datang ke toko, cukup melihat dan melakukan transaksi pada web yang tersedia, sehingga tidak membutuhkan waktu yang cukup banyak, dan Perancangan sistem Informasi ini bisa menjadi alat bantu perusahaan dalam mengelola transaksi dan pelaporan penjualan maupun pengiriman barang.

\section{REFERENSI}

Agustini, F. (2017). Sistem Informasi Penyewaan Kamar Menggunakan Metode Waterfall Dengan Konsep Pemrograman Berbasis Objek ( Studi Kasus : Hotel Bonita Cisarua Bogor ). Jurnal Teknik Komputer Amik Bsi, III(1), 114123.

Hendini, A. (2016). PEMODELAN UML SISTEM INFORMASI MONITORING PENJUALAN DAN STOK BARANG (STUDI KASUS: DISTRO ZHEZHA PONTIANAK). Jurnal Informatika Amik Pontianak, IV(2), 107-116.

Herliana, A. (2014). Analisa Dan Perancangan Sistem Informasi Administrasi Data Pribadi Dan Nilai Mahasiswa Di Perguruan Tinggi (Studi Kasus Universitas Kebangsaan Bandung). Jurnal Informatika Amik BSI Bandung, I(2), 82-92.

Lubis, R. (2017). Implementasi Program Persediaan Barang pada CV . Ardho Teknik Bekasi. JURNAL SISTEM INFORMASI STIMIK ANTAR BANGSA, VI NO.2(2), 172-180.

Natsari, G., Rosyida, S., \& Riyanto, V. (2014). Perancangan Sistem Informasi Penjualan Barang Distro Berbasis Web. Jurnal Teknologi dan Sistem Komputer AMIK BSI Bekasi, (2011), 66-72.

Setiawan, D. (2017). BUKU SAKTI PEMROGRAMAN WEB. (A. Sony, Ed.). Yogyakarta: START UP.

Sulianta, F. (2017). Teknik Perancangan Arsitektur Sistem Informasi. (Aditya, Ed.). Yogyakarta: ANDI.

Sutopo, P., Cahyadi, D., \& Arifin, Z. (2016). SISTEM INFORMASI EKSEKUTIF SEBARAN PENJUALAN KENDARAAN BERMOTOR RODA 2 DI KALIMANTAN TIMUR BERBASIS WEB. Jurnal Informatika Mulawarman, 11(1).

Taufik, Andi, E. (2017). Perancangan Sistem Informasi Pemesanan Pentas Seni Berbasis Web Pada Sanggar Seni Getar Pakuan Bogor. IJSE - Indonesian Journal on Software Engineering STMIK Nusa Mandiri Jakarta, 3(2), 1-7.

\section{PROFIL PENULIS}

[1] Bani Siregar

Lahir di Hutalobu tanggal 28 Mei 1994 Penulis Menamatkan kuliah D3 dari AMIK BSI Jakarta pada bulan Agustus 2018 dengan mengambil jurusan Manajemen Informatika atau sekarang menjadi jurusan Sistem Informatika Universitas BSI. Saat ini penulis bekerja di PT. Bangun Tiara Teknik.

[2] Firstianty Wahyuhening Fibriany

Lahir di Jakarta tahun 1978. Penulis lulusan S1 jurusan Teknologi Industri Pertanian IPB dengsn tahun lulus 2000 dan lulusan S2 Magister Manajemen IPB dengan tahun lulus 2003. Saat ini penulis bekerja di jurusan Sistem Informasi Unuversitas BSI. Penulis bergabung dengan BSI sejak tahun 2010 dengan status dosen luar biasa. 